\title{
A historical kaleidoscope of public communication of science and technology
}

\section{Luisa Massarani, Ildeu de Castro Moreira and Bruce Lewenstein}

\begin{abstract}
Science communication is today a well-established —although youngarea of research. However, there are only a few books and papers analyzing how science communication has developed historically. Aiming to, in some way, contribute to filling this gap, JCOM organized this special issue on the History of Public Communication of Science and Technology (PCST), joining 15 contributions, from different parts of the globe. The papers published in this issue are organized in three groups, though with diffuse boundaries: geography, media, and discipline. The first group contains works that deal descriptively and critically with the development of PCST actions and either general or specific public policies for this area in specific countries. A second set of papers examines aspects of building science communication on TV or in print media. The third group of papers presents and discusses important PCST cases in specific areas of science or technology at various historical moments.
\end{abstract}

Keywords

History of public communication of science; Public engagement with science and technology; Science communication in the developing world

Science communication is today a well-established - although young - area of research. It is a transdisciplinary area that incorporates methodologies, practices and insights from several other research domains. However, the activities of public communication of science and technology began many centuries ago, along with all the other origins of modern science. The study of the history of public communication of science and technology not only helps us understand how its forms have changed over time, but also help us understand philosophical suppositions concerning science, scientific understandings of the world at particular times, underlying cultures in which science and technology developed, the political and economic interests and the media available in different times and places, and so on. According to Raichvarg and Jacques, among the first historians in this area, the history of science communication is also "an indispensable complement to the history and philosophy of the sciences, insofar as it gives rise to new questions: why, for whom and how a science, at a particular time, was spread through the social fabric of an era; who made this science theirs in a particular era and by what means". ${ }^{1}$ However, there are only a few books and papers analyzing how science communication has developed historically - and the gap is especially evident when we look to the developing world.

${ }^{1}$ D. Raichvarg et J. Jacques, Savants et Ignorants, Paris: Éd. Le Seuil, 1991, p. 8. 
Aiming to, in some way, contribute to filling this gap, JCOM invited papers for this special issue on the History of Public Communication of Science and Technology (PCST). We invite you to read critically these contributions, considering how they inform our picture of the field. About 30 papers were submitted from all continents (except Antarctica!), written by researchers with different backgrounds and viewpoints, bringing a wide range of perspectives on the subject. Following rigorous peer-review, 15 papers were selected and are published now, just ahead of a symposium we are organizing on the history of PCST at the 25th International Congress of History of Science and Technology, being held in July 2017 in Rio de Janeiro.

The papers published in this issue are organized in three groups, though with diffuse boundaries: geography, media, and discipline. The first group contains works that deal descriptively and critically with the development of PCST actions and either general or specific public policies for this area in specific countries. A second set of papers examines aspects of building science communication on TV or in print media. The third group of papers presents and discusses important PCST cases in specific areas of science or technology at various historical moments.

In the first group, we pooled papers that reflect on the history of PCST in different countries: Australia, Japan, New Zealand, South Africa, Brazil and Spain. These papers invite us to think about the different paths that PCST took in different contexts and thus the different kinds of challenges that it faced.

Toss Gascoigne and Jenni Metcalfe chart the emergence of modern science communication over the last 60 years in Australia, comparing it against an international background. They argue that this period has seen the birth of interactive science centers, the first university courses to teach the theory and practice of science communication, the first university departments conducting research into science communication, and a sharp growth in employment of science communicators by research institutions, universities, museums, science centers and industry. Their gradual story contrasts with the one in Japan described by Masataka Watanabe. He argues that a single event, the Great East Japan Earthquake in 2011, significantly changed the Japanese people's awareness of science communication; he raises the questions: Why was such a policy shift possible? How did such a cascade effect occur? Looking at a much longer historical arc, Jean S Fleming and Jeremy Star discuss the emergence of science communication in Aotearoa New Zealand, arguing the history of science communication there starts with the stories told by the indigenous Maori people and has often been rooted in large, controversial environmental or technological issues. They claim that a more critical and strategic approach to science communication in the future is needed if New Zealand wants a more science-literate public, and a more public-literate science community.

Illustrating the importance of politics, Hester du Plessis explores some of the reasons behind the neglect of science communication in South Africa and argues that two political systems can be identified as having had a profound impact on the lack of attention given to this research field: the 'divide and rule' system of British colonialism and the Afrikaner National Party 'apartheid' system of racial segregation. Also highlighting politics, Lourdes López-Pérez and María Dolores Olvera-Lobo map the history of public communication of science in Spain. They argue that the political and economic history of the country shaped the evolution of this area as it emerged in the country in the second half of the 20th century with the proliferation of initiatives such as the creation of science museums, the building of 
the Spanish Science Foundation and the development of a public Scientific Information service. Finally, Jessica Norberto Rocha and Martha Marandino explore the development process for mobile science museums and centers in international contexts and discuss, especially in Brazil, the public policies and the particular initiatives that are involved. After they present some milestones in the history of mobile science museum and centers in Brazil, they present the main challenges currently faced by them.

The first paper of the second group, written by Allan Jones, uses 'scientific exceptionalism' to explore a history of scientists' claims for special treatment. He focuses on the lobby held, over several decades, by groups of scientists at the British Broadcasting Corporation (BBC), as they argued that science broadcasting should be given exceptional treatment both in its content and in its managerial arrangements. The article looks at the nature of this exceptionalism and broadcasters' responses to it. The focus changes to print publication, as Arko Olesk analyses science coverage in the Soviet Estonian publications Rahva Hä̈l and Horisont in 1960/1967 and 1980 and demonstrates that the popularization of science existed as an independent function of articles, beyond ideological propaganda. Also looking at print, Maria Rachel Fróes da Fonseca looks at the last decades of the 19th century, when education was a central concern in Mexican society, considered the main mechanism for the transformations that the country needed. The author looked at the Mexican magazine La ciencia recreativa (Recreative science), written for children and the working classes and published between 1871 and 1879; it was based on the idea of making science accessible for all, built on the conviction that the growing field of science was an instrument for knowledge of new nations and training of the people.

The historical analysis of PCST cases in specific areas of science and technology is the objective of the third group of papers. Merryn McKinnon and Lindy A. Orthia compare Australian government vaccination campaigns from two very different time periods, the early nineteenth century and the early twenty-first. The analysis shows that modern campaigns rely primarily on scientific fact, whereas 200 years ago personal stories and emotional appeals were more common. She argues that a return to the old ways may be needed to address vaccine hesitancy around the world. Thomas Lean and Sally Horrocks look at the British electricity industry and the communication of nuclear power to the public, in the period of 1950s-1980s, based on oral history interviews and archival material. Eugenio Bertozzi's attention is focused on a specific episode of 20th Century physics - the discovery of parity violation in 1957- and presents a study of the types of explanations of the crucial experiment as they are found in different editorial categories: a peer-reviewed journal, a popular science book, an encyclopedia and newspaper articles. The paper presents a reflection on the processes of transformation and adaptation implied by the circulation of knowledge and shows that a focus on explanation can offer further insights to current historical research on science communication.

Mireia Fernández-Ardèvol and Jordi Ferran Boleda explore the combined effects of mobile telephony and advertisements as a way for doing science popularization in Spain. They suggest that the analysis of advertisements that promote everyday digital devices allows a better understanding of what (digital) technology means to publics. Looking at a specific medical field, Diana Garrisi discusses the role of a Victorian newspaper correspondence column (in The Times) in advancing knowledge of dermatology in relation to corporal punishment. She uses the coverage of an inquest into the death by flogging of a British soldier to explore the 
arguments of The Times in the debate on corporal punishment, and its strategy to maintain authority and credibility against accusations of sensationalism. Carolina Carvalho, Cátia Matias and Sérgio Marcondes discuss the processes of communication and circulation of knowledge in psychology in Brazil during the decades of 1930 and 1940, looking specifically at the psychiatrist Henrique Roxo. The article puts into discussion the question of who has authority to speak of science and the differences of writing and language as understood by the non-expert public.

Certainly the collection of papers gathered here provides good starting material for analyses of aspects of the history of science communication in various domains and countries. However, as a still young domain of research, historical studies on PCST still comprise a kaleidoscopic picture —we're seeing just bits and pieces, coming together in constantly changing patterns. Investigating other cases and situations, weaving new connections, establishing general relationships, generating and elucidating larger conceptual issues remain important challenges for future studies and further work in this area.

We thank everyone who contributed to this special issue, especially the authors who submitted their manuscripts and the reviewers who helped assess and in many cases improve them. We hope readers will gain a better historical view of this area and perhaps be inspired to investigate and discuss aspects of the development of science communication in the areas in which they work.

Luisa Massarani is a Brazilian science communicator and Executive Director of the Red de Popularización de la ciencia y la tecnología en América Latina y el Caribe (Latin American and Caribbean Network for the Popularisation of Science and Technology) (RedPOP). She organizes practical and academic activities in science communication. She is a member of the Núcleo de Estudos da Divulgação Científica (Center of Science Communication Studies) of the Museu da Vida, Casa de Oswaldo Cruz, Fundação Oswaldo Cruz, in Brazil. At this institution, she coordinates the Master in Communication of Science, Technology and Health, established in 2016. She is the coordinator for Latin America and the Caribbean of SciDev.Net (www.scidev.net). She is the recipient of the Brazilian Award for Science Communication "Premio José Reis de Divulgação Científica", in 2016. E-mail: luisa.massarani5@gmail.com.

Ildeu Moreira is a physicist, professor at the Federal University of Rio de Janeiro. He teaches Physics, History of Science and Science Communication. He is the vice-president of the Brazilian Society for the Advancement of Science. He is the recipient of the Brazilian Award for Science Communication "Premio José Reis de Divulgação Científica", in 2013. E-mail: ildeucastro@gmail.com.

Bruce V. Lewenstein is Professor of Science Communication and Chair of the Department of Science \& Technology Studies at Cornell University. Member of JCOM Editorial Advisory Board. E-mail: b.lewenstein@cornell.edu.

How to cite 